\title{
BMJ Open Cohort profile: Japanese human milk study, a prospective birth cohort: baseline data for lactating women, infants and human milk macronutrients
}

\author{
Keisuke Nojiri, ${ }^{1}$ Satoshi Higurashi, ${ }^{1}$ Tomoki Takahashi, ${ }^{1}$ Yuta Tsujimori, ${ }^{1}$ \\ Shunjiro Kobayashi, ${ }^{2}$ Yasuhiro Toba, ${ }^{1}$ Jun-ichi Yamamura, ${ }^{2}$ Kyoko Nomura, ${ }^{3}$ \\ Hiroshi M Ueno (1) ${ }^{2}$
}

To cite: Nojiri K, Higurashi S, Takahashi T, et al. Cohort profile: Japanese human milk study, a prospective birth cohort: baseline data for lactating women, infants and human milk macronutrients. BMJ Open 2021;11:e055028. doi:10.1136/ bmjopen-2021-055028

- Prepublication history and additional supplemental material for this paper are available online. To view these files, please visit the journal online (http://dx.doi.org/10.1136/ bmjopen-2021-055028).

Received 02 July 2021 Accepted 03 December 2021

Check for updates

(c) Author(s) (or their employer(s)) 2021. Re-use permitted under CC BY-NC. No commercial re-use. See rights and permissions. Published by BMJ.

${ }^{1}$ Department of Research and Development, Bean Stalk Snow Co., Ltd, Kawagoe, Japan ${ }^{2}$ Megmilk Snow Brand Co., Ltd, Kawagoe, Japan

${ }^{3}$ Department of Environmental Health Science and Public Health, Akita University Graduate School of Medicine, Akita, Japan

Correspondence to

Dr Hiroshi M Ueno;

hiroshi-ueno@meg-snow.com

\section{ABSTRACT}

Purpose The Japanese Human Milk Study, a longitudinal prospective cohort study, was set up to clarify how maternal health, nutritional status, lifestyle and sociodemographic and economic factors affect breastfeeding practices and human milk composition. This would eventually determine factors affecting the growth and development of infants and children.

Participants A total of 1210 Japanese lactating women who satisfied the inclusion criteria, were invited across the country at various participating sites, between 2014 and 2019. Finally a total of 1122 women were enrolled in this study.

Findings to date Among 1122 eligible participants, mean age at delivery was 31.2 (SD 4.4) years and mean prepregnancy BMI was 20.8 (SD 2.7). Among these women, $35 \%$ were previously nulliparous and $77.7 \%$ had college, university or higher education. The mean gestational period was 39.0 (SD 1.3) weeks. Caesarean section was reported among 11.9\%; mean infant birth weight was 3082 (SD 360) g. Of the infants, $53.7 \%$ were male. Overall, our participants appeared to be healthier than the general population in Japan. Analyses of the 1079 eligible human milk samples obtained at the first and second months postpartum showed the following composition: carbohydrate, 8.13 (SD 0.32) g/100 mL; fat, 3.77 (SD 1.29) g/100 mL; and crude protein, 1.20 (SD 0.23) $\mathrm{g} / 100 \mathrm{~mL}$. We also analysed osteopontin, fatty acid, vitamin D and phospholipid levels in limited subcohorts of the samples. Future plans Follow-up surveys will be conducted to obtain milk samples every 2 months for 12 months and to investigate mother and child health until the children reach 5 years of age. These will be completed in 2024 . We plan to longitudinally analyse the composition of macronutrients and various bioactive factors in human milk and investigate the lifestyle and environmental factors that influence breastfeeding practices, maternal and child health, and child development.

Trial registration number UMIN000015494; pre-results.

\section{INTRODUCTION}

The WHO recommends exclusive breast feeding for the first 6 months of life to promote optimal health and development of infants. ${ }^{1}$ Breast feeding is beneficial for
Strengths and limitations of this study

- The Japanese Human Milk Study is a nationwide, longitudinal prospective cohort study of more than 1000 lactating mother-infant dyads in Japan.

- This study will collect a wide range of data on maternal factors (sociodemographic, economic and lifestyle-related factors), along with data on development of children over a period of 5 years.

- The sufficient amount of milk samples allows for a comprehensive compositional analysis and their associations in the mother-milk-infant triad.

- One of the study limitations is lack of information on maternal nutrition and lifestyle during pregnancy.

both mothers and infants. Breastfed infants exclusively for the first 6 months have fewer infections, including respiratory illnesses and diarrhoea. ${ }^{2}$ For lactating women, breast feeding might prevent reproductive cancers (such as breast and ovarian cancers) and type 2 diabetes. ${ }^{2}$ Furthermore, recent data suggest that breast feeding may determine prolonged health consequences among children including neurodevelopment, lifestyle diseases and malignancy. ${ }^{2}$ The benefits of breast feeding have been discussed in relation to the composition of human milk.

Human milk contains numerous compounds and provides nutrition and many bioactive components to the infants. ${ }^{3}$ Human milk composition changes throughout the lactation period and has been widely studied in different countries. ${ }^{3}$ A recent review suggested that human milk composition can be influenced by a variety of factors such as the maternal diet, physical characteristics and socioeconomic status. ${ }^{4}$ However, the review also provided evidence that data for those factors are still inconsistent or lacking. ${ }^{4}$ The inconsistency of evidence may be influenced 
by differences in the residential environment of mothers and infants. Different lifestyles and environment in countries and regions appear to influence the composition of human milk. For Japanese populations, the concentration of docosahexaenoic acid (DHA) in human milk varied widely around the world, and Japan was one of the countries with the highest concentration of DHA in human milk. ${ }^{5}$ One of the public health challenges in Japan is the high rate of low-birthweight (LBW) infants, which was $9.4 \%$, while the Country average in the Organisation for Economic Co-operation and Development was $6.5 \%$ in $2017 .{ }^{6}$ Recent studies suggest that maternal characteristics, mainly underweight, may explain the high percentage of LBW infants in Japan. ${ }^{78}$ Thus, we investigated in our Japanese cohort the effects of maternal factors on breastmilk composition and effects of breast feeding on the maternal and infant health outcomes.

Human milk studies have been conducted in Japan for a long time, including studies by our research group in 1960 and $1989,{ }^{10}$ and recent studies have focused on different areas. ${ }^{11-13}$ However, none of these studies focused on the effects of maternal characteristics, including socioenvironmental factors, on human milk composition, feeding practices and child development. We hypothesised that maternal characteristics, including socioenvironmental factors, may influence human milk composition, feeding practices and child development in the Japanese population. Therefore, we designed this prospective cohort study to investigate maternal health status, nutrition, lifestyle, and sociodemographic and economic factors, and to clarify whether these factors are linked to breastfeeding practices and human milk composition and/or are associated with the growth and development of children through differences in human milk composition. ${ }^{14}$

This paper summarises the cohort profile and the baseline characteristics of all eligible participants at the start of the investigation. The baseline data allow us to discuss the generalisability, strengths and limitations of this cohort study. Our study could also provide additional information about nationwide birth cohort including human milk samples in Japan.

\section{COHORT DESCRIPTION}

Since the detailed study design and protocol of the Japanese Human Milk Study have been published elsewhere, ${ }^{14}$ cohort descriptions are briefly summarised in this paper.

\section{Study design}

The Japanese Human Milk Study is a longitudinal prospective cohort study of lactating Japanese women and their infants and children. We collected human milk samples and information related to various health parameters from mother-child dyads. Collection of milk samples and health information was performed every 2 months during the first year after birth. After 1 year, follow-up surveys were conducted at 18, 24, 36, 48 and 60 months, and health information was collected longitudinally.

\section{Study participants}

Our study participants were recruited at between first 60 days postpartum from 73 medical institutions, including 16 hospitals and obstetrics clinics, across Japan between October 2014 and May 2019 (enrolment period). When lactating women visited hospitals and clinics, they were invited to participate in the study. Our trained staff explained the purpose of this study; then, questionnaires and sterile plastic bags for human milk collection were mailed to those who provided informed consent. We then followed up by mail, email and phone call for up to 5 years, at which time the study was completed. The inclusion criteria were as follows: (1) healthy singleton infants aged less than 60 days and (2) healthy lactating women who had delivered infants and experienced no disruptions in their breastfeeding patterns when providing human milk samples for this study. The exclusion criteria were as follows: (1) hepatitis B-positive or hepatitis C-positive individuals, or patients with HIV or human T-cell leukaemia virus type 1 infections; (2) patients who were on medication for underlying illnesses; (3) individuals who did not breast feed; and (4) mothers, partners or children who were not of Japanese ethnicity. The infants and their siblings, partners (fathers) and grandparents were also surveyed through mothers.

Figure 1 shows the flowchart of this study from enrolment to identification of valid respondents and collection of human milk samples at baseline. We recruited 1210 lactating women; however, 83 did not provide valid responses and 5 met the exclusion criteria: the women or their partners were not Japanese. Thus, 1122 women were included in the study, of whom 1079 provided human milk samples during the first study period (baseline).

\section{Data collection}

Sociodemographic factors, health status and dietary patterns among mothers, and the physical and psychological development of infants

Data were collected using original basic questionnaires and validated and reliable scales: a Brief-Type Selfadministered Diet History Questionnaire for maternal diet, ${ }^{15}$ Kinder Infant Development Scale for physical and psychological development of infants ${ }^{16}$ and mother's Child Care Stress Scale for maternal nursing distress. ${ }^{17}$ The maternal baseline profile included sociodemographic characteristics (age and season at delivery), socioeconomic profile (family structure, household income, educational attainment and employment status, including the status of the partner), lifestyle and medical history (smoking status and prevalence of allergies, including those in the respondent's partner), pregnancy outcomes (parity) and physical health (height, prepregnancy weight and prepregnancy body mass index (BMI)). Prepregnancy BMI was calculated using height and weight and categorised with reference to the following WHO definitions: $<18.5 \mathrm{~kg} / \mathrm{m}^{2}$, underweight; $18.5-24.9 \mathrm{~kg} / \mathrm{m}^{2}$, normal weight; and $\geq 25.0 \mathrm{~kg} / \mathrm{m}^{2}$, obesity. ${ }^{18}$ The infant baseline profile included sex, gestational age, mode of 


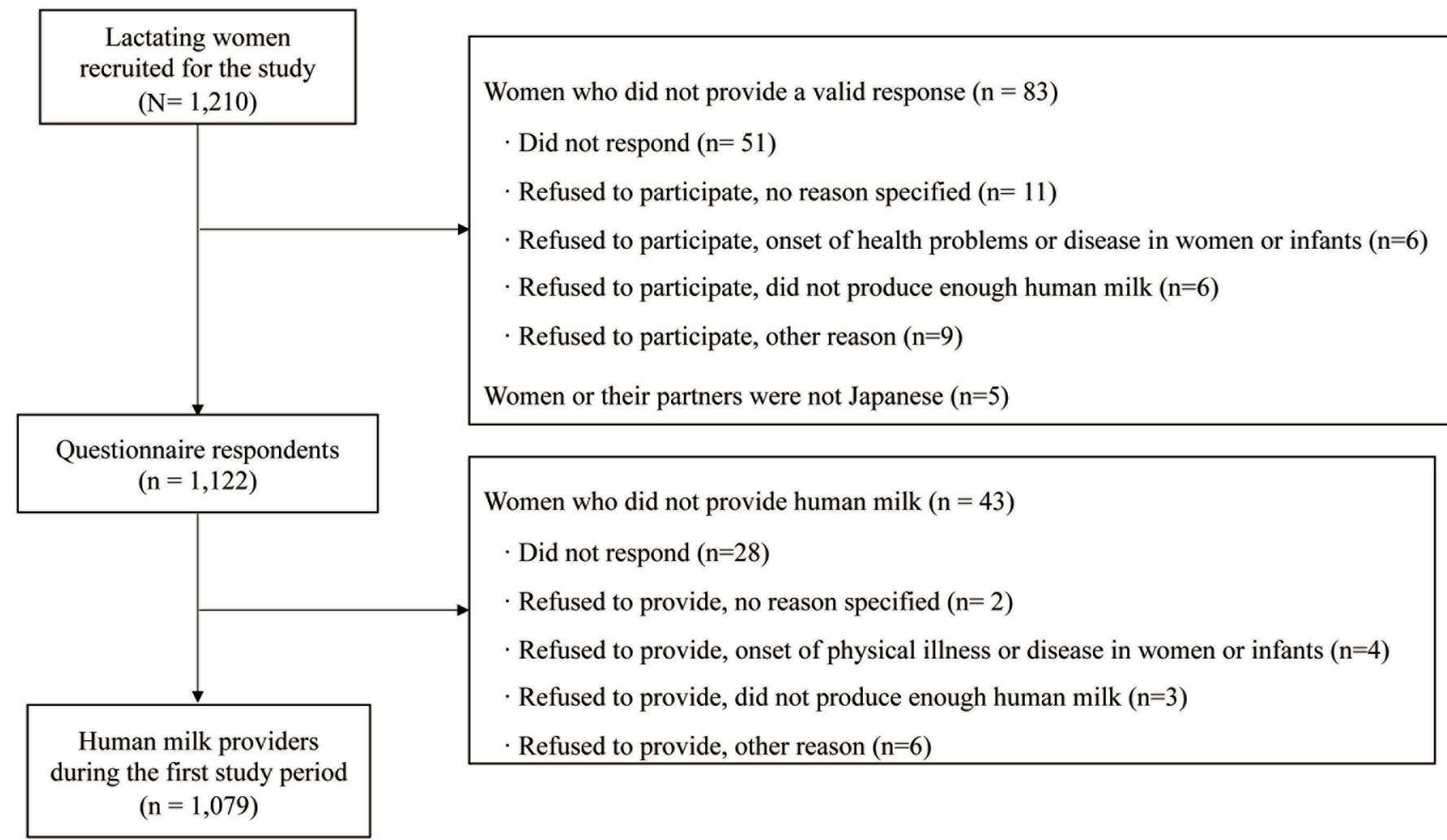

Figure 1 Flow diagram of the study participants.

delivery, birth weight, birth height, birth head circumference, and feeding status, including breast feeding.

Human milk collection and analysis

Milk samples were provided from the study participants with sufficient milk supply and willing to collect milk samples. We defined a human milk provider as an individual who had sufficient milk supply and agreed to provide human milk, while non-providers had any reasons not to provide milk samples as summarised in figure 1 . Approximately $10-20 \mathrm{~mL}$ human milk samples were obtained after their breast feeding using a manual breast pump that was transferred to a milk storage container, and stored at $-18^{\circ} \mathrm{C}$ once a day for 7 days. Milk samples were obtained from the participants via a fast frozen delivery service and stored at $-80^{\circ} \mathrm{C}$ until analysis. Macronutrients, total solid and energy levels were measured using a mid-infrared milk analyser (MIRIS; Miris holding, Uppsala, Sweden) in the thawed and mixed individual containers. The intraday precisions were $0.43 \%, 1.81 \%$, $1.86 \%, 1.38 \%, 0.29 \%$ and $0.20 \%$ for carbohydrate, fat, crude protein, true protein, total solid and energy in the repeated measurement of the reference human milk sample for six times, respectively.

\section{Patient and public involvement}

The participants and the public were not involved in the design and conduct of this study. Study updates are regularly shared with the public through corporate websites, email newsletters and fact sheets for healthcare professionals.

\section{FINDINGS TO DATE}

\section{Baseline characteristics}

Parents

The baseline characteristics of the mothers and their partners are summarised in tables 1 and 2. The mean age at birth was 31.2 (SD 4.4) years, and the birth season was equally distributed throughout the year. Most mothers had nuclear families with only her partner and their children $(86.3 \%)$. Household income of the participants generally ranged from 4 to 6 million Japanese yen (JPY, US $\$ 1$ is approximately $110 \mathrm{JPY}$ ) for $35.5 \%$ and $2-8$ million JPY for $84.2 \%$ of the study population. The national statistics in 2016 reported that the average and median household incomes for all households were 5.45 million JPY and 4.27 million JPY, respectively. ${ }^{19}$ Of the 1116 women who responded to the questionnaire, $22.3 \%$ had graduated from junior high school, high school or others, while the remaining $77.7 \%$ had graduated from college or university or had a higher degree. Almost half of the mothers $(42.8 \%)$ were homemakers or unemployed. Smoking history was observed in $30.4 \%$ of the women, but most of them had quit before or during pregnancy. A history of allergic diseases was recorded in $61.7 \%$ of the women, with allergic rhinitis being the most prevalent $(35.4 \%)$. One-third of the mothers $(35.0 \%)$ were previously nulliparous, while $44.1 \%$ had another child at the time of study enrolment. The mean prepregnancy BMI was 20.8 (SD 2.7) $\mathrm{kg} / \mathrm{m}^{2}$, with $15.8 \%$ and $7.0 \%$ of the mothers being classified as underweight and obese, respectively. Among the partners who provided valid responses $(n=1121)$, 
Table 1 Baseline profiles of the mothers

\begin{tabular}{|c|c|c|c|c|}
\hline Variables & Valid response (n) & $\mathbf{n}$ & $\%$ & Mean (SD) \\
\hline Age at delivery (years) & 1122 & & & $31.2(4.4)$ \\
\hline$<20$ & & 2 & 0.2 & \\
\hline $20-24$ & & 58 & 5.2 & \\
\hline $25-29$ & & 341 & 30.4 & \\
\hline $30-34$ & & 464 & 41.4 & \\
\hline $35-39$ & & 214 & 19.1 & \\
\hline$\geq 40$ & & 43 & 3.8 & \\
\hline Season at delivery & 1122 & & & \\
\hline Spring (March-May) & & 284 & 25.3 & \\
\hline Summer (June-August) & & 264 & 23.5 & \\
\hline Autumn (September-November) & & 285 & 25.4 & \\
\hline Winter (December-February) & & 289 & 25.8 & \\
\hline Family structure & 1118 & & & \\
\hline Single parent & & 4 & 0.4 & \\
\hline Nuclear family & & 965 & 86.3 & \\
\hline Extended family & & 149 & 13.3 & \\
\hline Household income from all sources (million JPY/year) & 1078 & & & \\
\hline$<2$ (<US\$18 000/year) & & 16 & 1.5 & \\
\hline 2 to $<4$ (US $\$ 18000$ to $<$ US $\$ 36000 /$ year) & & 271 & 25.1 & \\
\hline 4 to $<6$ (US\$36 000 to $<$ US $\$ 55$ 000/year) & & 383 & 35.5 & \\
\hline 6 to $<8$ (US\$55 000 to $<$ US $\$ 73$ 000/year) & & 254 & 23.6 & \\
\hline 8 to $<10$ (US $\$ 73000$ to $<$ US $\$ 91$ 000/year) & & 91 & 8.4 & \\
\hline$\geq 10$ (US $\$ \geq 91$ 000/year) & & 63 & 5.8 & \\
\hline Education & 1116 & & & \\
\hline JHS/HS/others & & 249 & 22.3 & \\
\hline Some college/technical & & 469 & 42 & \\
\hline 4-year college/graduate degree & & 398 & 35.7 & \\
\hline Employment & 1117 & & & \\
\hline Independent or family business & & 38 & 3.4 & \\
\hline Full-time employment, permanent & & 344 & 30.8 & \\
\hline Full-time employment, temporary & & 30 & 2.7 & \\
\hline Part-time employment & & 89 & 8 & \\
\hline Unemployment/homemaker & & 478 & 42.8 & \\
\hline Leave of absence & & 138 & 12.4 & \\
\hline Smoking status & 1118 & & & \\
\hline Never smoked & & 778 & 69.6 & \\
\hline Ex-smoker, quit before pregnancy & & 190 & 17 & \\
\hline Ex-smoker, quit during pregnancy & & 119 & 10.6 & \\
\hline Ex-smoker, quit after delivery & & 8 & 0.7 & \\
\hline Smoker, but refrained during pregnancy & & 11 & 1 & \\
\hline Smoker, continuously & & 12 & 1.1 & \\
\hline Medical history of allergy & 1092 & & & \\
\hline Asthma & & 96 & 8.8 & \\
\hline Food allergy & & 77 & 7.1 & \\
\hline Atopic dermatitis & & 137 & 12.5 & \\
\hline
\end{tabular}


Table 1 Continued

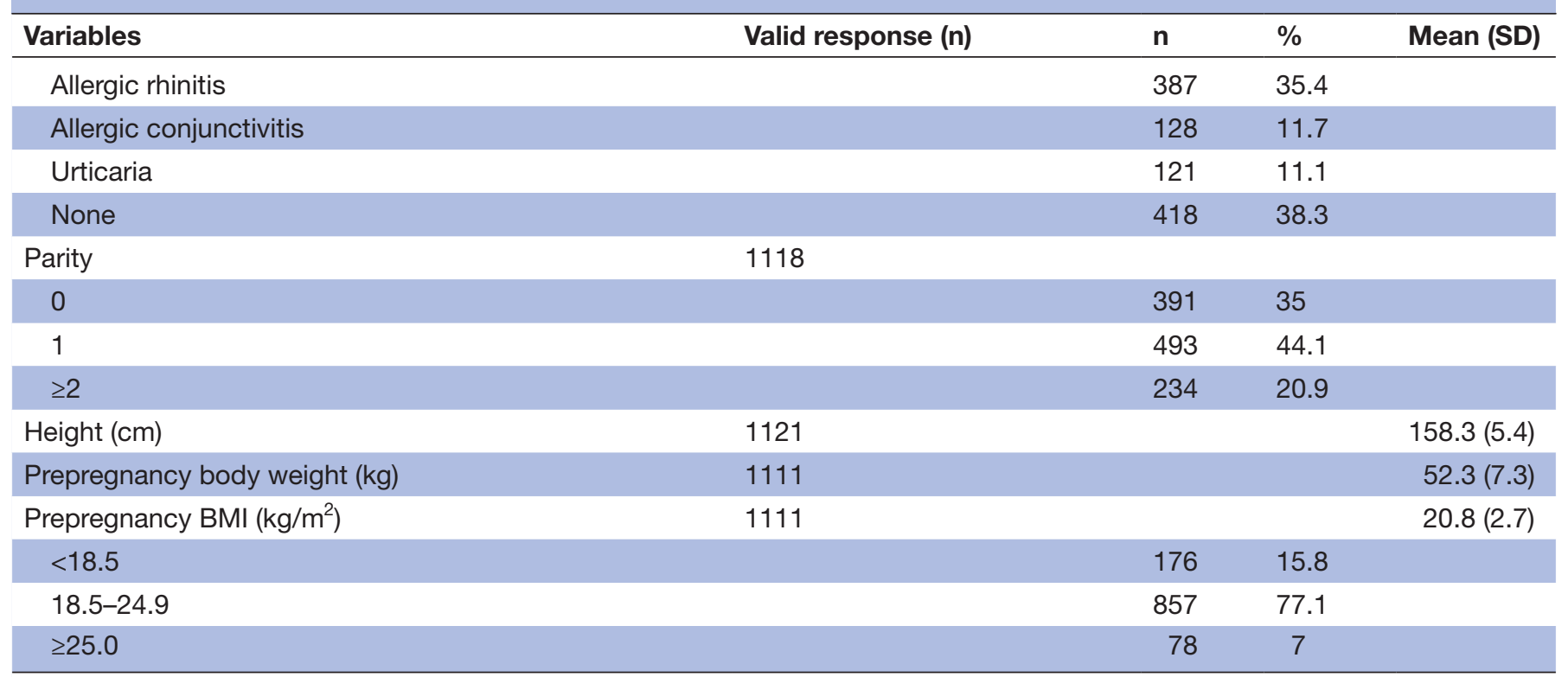

BMI, body mass index; HS, high school; JHS, junior high school; JPY, Japanese yen.

$66.4 \%$ had graduated from college or university or higher educational institutions; $84.5 \%$ worked in private companies and public organisations as full-time workers; $37.7 \%$ were current smokers; and $32.0 \%$ had allergic rhinitis.

\section{Infants}

Birth-related baseline characteristics are presented in table 3 . The majority $(97.2 \%)$ of infants were born fullterm; $53.7 \%$ of the infants were boys, and caesarean deliveries accounted for $11.9 \%$ of the births. The mean birth weight, height and head circumference were 3082 (SD 360) g, 49.3 (SD 1.8) cm and 33.4 (1.9) cm respectively, while the proportion of low-birthweight infants $(<2500 \mathrm{~g})$ was $4.3 \%$. With respect to feeding methods, $74.6 \%$ of the infants were exclusively breast fed at the baseline of a mean 55.1 (SD 19.6) days postpartum. The baseline characteristics were comparable, including breastfeeding status between the human milk providers and non-human milk providers (online supplemental tables 1-3).

\section{Human milk macronutrients}

Table 4 shows the macronutrient, total solid and energy content in human milk at baseline. A total of 1079 milk samples were obtained. Mean concentrations of macronutrients were 8.13 (SD 0.32) g/ $100 \mathrm{~mL}$ for carbohydrate, 3.77 (SD 1.29) g/100 mL for fat, $1.20(\mathrm{SD} 0.23) \mathrm{g} / 100 \mathrm{~mL}$ for crude protein, 0.95 (SD 0.18) $\mathrm{g} / 100 \mathrm{~mL}$ for true protein, 13.3 (SD 1.3) g/100 mL for total solids and 72.6 (SD 12.0) kcal $/ 100 \mathrm{~mL}$ for energy content, respectively. The mean time point for collection of baseline human milk samples was 53.8 (SD 17.8) days postpartum.

The composition of human milk was comparable to that reported in previous studies. ${ }^{20-22}$ We used mid-infrared spectrophotometer that was specifically developed for the evaluation of human milk and calibrated to human milk values for analysing the milk macronutrients and energy content. ${ }^{23}$ In this study, fat was the most variable macronutrient in human milk, which is consistent with the literature on mature milk. ${ }^{24}$ Milk fat content varies according to the residual milk content of the breast at sampling (eg, fore, middle and hind milk), ${ }^{25}$ as well as other factors such as the day-night cycle ${ }^{26}$ and maternal $\mathrm{BMI}^{27}$ Our results indicated that the average composition of human milk was a combination of fore and hind milk, ${ }^{25}$ similar to the findings of other studies using the same technique. ${ }^{20-22}$ Milk protein content was the highest in the colostrum and declined by approximately $25 \%$ in the first month of life, gradually declining thereafter to approximately $50 \%$ by the infant's first year of life. ${ }^{28}$ The protein concentrations in this study were similar to those reported for similar lactation periods in previous studies. ${ }^{20-22}$ The mean carbohydrate value of 8.1 (SD 0.3) $\mathrm{g} / 100 \mathrm{~mL}$ in this study was within the range described in the literature using MIRIS. ${ }^{20-22}$ Carbohydrate content in milk had relatively little individual variation as compared with fat and protein concentrations in our study. However, other studies using the same methodology (MIRIS) have reported some variations, with mean or median carbohydrate concentrations ranging from 7.0 to $8.7 \mathrm{~g} / 100 \mathrm{~mL} .^{20-22}$ Although an infrared spectrophotometer such as MIRIS is accurate and reliable for measuring proteins and fat, the accuracy of carbohydrate measurements is reported to be limited and varies widely among instruments. ${ }^{29} 30$ Therefore, caution should be exercised in comparing carbohydrate contents between studies.

\section{Findings to date from the Japanese human milk study}

Since data collection began in 2014, the subcohort studies conducted in the Japanese Human Milk Study have 
Table 2 Baseline profiles of the partners

\begin{tabular}{|c|c|c|c|}
\hline Variables & $\begin{array}{l}\text { Valid response } \\
\text { (n) }\end{array}$ & $\mathbf{n}$ & $\%$ \\
\hline Education & 1115 & & \\
\hline JHS/HS/others & & 375 & 33.6 \\
\hline $\begin{array}{l}\text { Some college/ } \\
\text { technical }\end{array}$ & & 217 & 19.5 \\
\hline $\begin{array}{l}\text { 4-year college/ } \\
\text { graduate degree }\end{array}$ & & 523 & 46.9 \\
\hline Employment status & 1115 & & \\
\hline $\begin{array}{l}\text { Independent or } \\
\text { family business }\end{array}$ & & 121 & 10.9 \\
\hline $\begin{array}{l}\text { Fulltime } \\
\text { employment, } \\
\text { permanent }\end{array}$ & & 942 & 84.5 \\
\hline $\begin{array}{l}\text { Fulltime } \\
\text { employment, } \\
\text { temporary }\end{array}$ & & 27 & 2.4 \\
\hline $\begin{array}{l}\text { Part-time } \\
\text { employment }\end{array}$ & & 7 & 0.6 \\
\hline $\begin{array}{l}\text { Unemployment/ } \\
\text { homemaker }\end{array}$ & & 6 & 0.5 \\
\hline Leave of absence & & 4 & 0.4 \\
\hline $\begin{array}{l}\text { Unknown or no } \\
\text { partner }\end{array}$ & & 5 & 0.4 \\
\hline Others & & 3 & 0.3 \\
\hline Smoking status & 1119 & & \\
\hline Never smoked & & 417 & 37.3 \\
\hline $\begin{array}{l}\text { Ex-smoker, quit } \\
\text { before pregnancy }\end{array}$ & & 199 & 17.8 \\
\hline $\begin{array}{l}\text { Ex-smoker, quit } \\
\text { during pregnancy }\end{array}$ & & 47 & 4.2 \\
\hline $\begin{array}{l}\text { Ex-smoker, quit } \\
\text { after delivery }\end{array}$ & & 31 & 2.8 \\
\hline $\begin{array}{l}\text { Smoker, but } \\
\text { refrained during } \\
\text { pregnancy }\end{array}$ & & 10 & 0.9 \\
\hline $\begin{array}{l}\text { Smoker, } \\
\text { continuously }\end{array}$ & & 412 & 36.8 \\
\hline $\begin{array}{l}\text { Unknown or no } \\
\text { partner }\end{array}$ & & 3 & 0.3 \\
\hline $\begin{array}{l}\text { Medical history of } \\
\text { allergy }\end{array}$ & 1088 & & \\
\hline Asthma & & 96 & 8.8 \\
\hline Food allergies & & 67 & 6.2 \\
\hline Atopic dermatitis & & 111 & 10.2 \\
\hline Allergic rhinitis & & 348 & 32 \\
\hline $\begin{array}{l}\text { Allergic } \\
\text { conjunctivitis }\end{array}$ & & 74 & 6.8 \\
\hline Urticaria & & 25 & 2.3 \\
\hline None & & 428 & 39.3 \\
\hline
\end{tabular}

HS, high school; JHS, junior high school.
Table 3 Baseline profiles of the infants

Valid

response

\begin{tabular}{lllll} 
Variables & $(\mathbf{n})$ & $\mathbf{n}$ & $\mathbf{\%}$ & Mean (SD) \\
\hline Sex & 1122 & & & \\
$\quad$ Male & & 602 & 53.7 & \\
$\quad$ Female & & 520 & 46.3 & \\
Gestational age & 1079 & & & $39.0(1.3)$
\end{tabular}

at birth (week)

\begin{tabular}{lrr}
$\begin{array}{l}\text { Preterm births } \\
(<37)\end{array}$ & 26 & 2.4 \\
\hline $\begin{array}{l}\text { Term births } \\
(37-41)\end{array}$ & 1049 & 97.2 \\
\hline
\end{tabular}

(37-41)

$\begin{array}{lll}\begin{array}{l}\text { Post-term } \\ \text { births }(\geq 42)\end{array} & 4 & 0.4\end{array}$

Mode of delivery 1117

$\begin{array}{lcc}\begin{array}{l}\text { Vaginal } \\ \text { delivery }\end{array} & 984 & 88.1 \\ \begin{array}{l}\text { Caesarean } \\ \text { section }\end{array} & 133 & 11.9\end{array}$

\begin{tabular}{|c|c|c|c|}
\hline Birth weight (g) & 1108 & & $3082(360)$ \\
\hline Male & 594 & & 3119 (370) \\
\hline Female & 514 & & 3039 (342) \\
\hline $\begin{array}{l}\text { Low birth } \\
\text { weight } \\
(<2500 \mathrm{~g})\end{array}$ & 48 & 4.3 & \\
\hline
\end{tabular}

Birth height $(\mathrm{cm}) 1103$

$49.3(1.8)$

$\begin{array}{cccc}\text { Male } & & 592 & 49.5(1.8) \\ \text { Female } & & 511 & 49.0(1.8) \\ \text { Birth head } & 1058 & & 33.4(1.9)\end{array}$

circumference

(cm)

\begin{tabular}{llll} 
Male & 565 & & $33.6(1.9)$ \\
\hline Female & 493 & & $33.2(1.9)$ \\
$\begin{array}{l}\text { Feeding status } \\
\begin{array}{l}\text { Exclusive } \\
\text { breast-feeding }\end{array}\end{array}$ & 835 & 74.6 & \\
$\begin{array}{l}\text { Non-exclusive } \\
\text { breast feeding }\end{array}$ & 285 & 25.4 & \\
\hline
\end{tabular}

contributed to various aspects of the literature regarding human milk composition. ${ }^{31-34}$

Osteopontin (OPN) concentration in human milk

OPN is a multifunctional protein that is present in various cells, tissues and body fluids. ${ }^{35}{ }^{36}$ Its concentration is the highest in milk and is significantly higher in humans than in cows. ${ }^{36}{ }^{37}$ We determined the OPN content in a large number of human milk samples from Danish, Chinese, Korean and Japanese mothers in a multicentre study. A total of 629 women provided 829 milk samples, of which 169 were obtained from 118 women recruited in an early phase of the Japanese Human Milk Study. We found that 
Table 4 Macronutrient, total solid and energy content in human milk

\begin{tabular}{lll}
\hline Variables & $\mathbf{n}$ & Mean (SD) \\
\hline Carbohydrate $(\mathrm{g} / 100 \mathrm{~mL})$ & 1079 & $8.13(0.32)$ \\
Fat $(\mathrm{g} / 100 \mathrm{~mL})$ & 1079 & $3.77(1.29)$ \\
Crude protein $(\mathrm{g} / 100 \mathrm{~mL})$ & 1079 & $1.20(0.23)$ \\
True protein $(\mathrm{g} / 100 \mathrm{~mL})$ & 1079 & $0.95(0.18)$ \\
Total solid $(\mathrm{g} / 100 \mathrm{~mL})$ & 1079 & $13.3(1.3)$ \\
Energy (kcal/100 $\mathrm{mL})$ & 1079 & $72.6(12.0)$ \\
Days postpartum $($ day) & 1079 & $53.8(17.8)$ \\
\hline
\end{tabular}

the milk OPN concentration and the OPN/protein $\%$ differed significantly between countries. ${ }^{31}$ Further, longitudinal measurement of OPN concentrations in human milk from the same mother showed a significant decrease throughout the lactation period. ${ }^{31}$ These results will contribute to a better understanding of the OPN content in human milk and facilitate the design of infant formula fortified with this bioactive protein abundantly found in human milk.

\section{Fatty acid (FA) composition in Japanese human milk}

FAs are one of the human milk nutrients affected by maternal nutritional status and may be involved in the neurological development of children. ${ }^{38}$ The DHA content in human milk varies greatly depending on the geographical location and local environmental factors, ${ }^{5}$ and has been shown to be historically higher in Japanese human milk samples than in samples from other countries. ${ }^{39}$ In this study, we characterised the FA composition in human milk and investigated the dietary and sociodemographic factors associated with the DHA concentration in human milk among 78 Japanese women recruited in an early phase of the Japanese Human Milk Study. We determined the levels of 14 saturated FAs, 7 monounsaturated FAs and 10 polyunsaturated FAs. Milk DHA levels were higher in women who routinely took DHA supplements than in women who did not take DHA supplements. ${ }^{32}$ A multivariate linear regression model showed an association between DHA concentration in human milk and maternal dietary intake of grilled fish, which is the most common method of cooking seafood in Japan, after adjustment for DHA supplementation use, maternal and infant age, maternal BMI and infant birth weight. ${ }^{32}$ These results will contribute to a better understanding of the FA composition in Japanese human milk. DHA concentrations in human milk in the present study were lower than those reported previously for Japanese samples (mean milk DHA concentration of $0.65 \%$ vs $0.99 \%^{39}$ and $1.09 \%^{40}$ ), which may reflect the reduced intake of fish in the Japanese population. ${ }^{41}$ Furthermore, DHA concentrations in human milk may reflect dietary habits, including DHA supplements, in Japanese women from a contemporary cohort.
Vitamin D (VD) concentrations in Japanese human milk

Recent studies have shown that VD deficiency is more common in pregnant and lactating women, ${ }^{42}$ and current VD concentrations in human milk might be lower than those in the past, increasing the risk of rickets in infants. Most of the VD is metabolised to 25-hydroxyvitamin D (25OHD), which circulates in the blood for a long time. Thus, 25OHD is an indicator of excess or deficiency of VD in the body as a nutrient. We compared VD and 25OHD concentrations in human milk collected in $1989(\mathrm{n}=72)$ and 2016-2017 $(\mathrm{n}=90)$ and evaluated seasonal differences too. This study was based on the data obtained by our research group at two different time points: one study performed in $1989^{10}$ and the ongoing Japanese Human Milk Study. ${ }^{14}$ The results showed that VD and 25OHD concentrations in human milk were higher in summer than in winter, irrespective of the study year, and lower in 2016-2017 than in the summer of $1989 .{ }^{33}$ A multiple regression analysis showed that season, daily outdoor activity and sun exposure over the last 12 months were associated with VD concentrations in human milk. ${ }^{33}$ These results suggest that the recent low VD status in lactating women may be associated with lower VD and 25OHD concentrations in human milk. This report underscores the need for improvement of the VD status in lactating women and infants, thus laying the foundation for a potentially useful public health strategy.

Phospholipid (PLs) concentrations in Japanese human milk

Supplementation of milk fat globule membranes has been implicated in the development of cognitive and gastrointestinal functions in childhood. ${ }^{43}$ PLs are one of the components of the milk fat globule membrane and are categorised under many different subclasses. ${ }^{44}$ We analysed various subclasses of PLs in human milk samples $(n=20)$ that had undergone FA measurements in a previous study. ${ }^{32} \mathrm{~A}$ total of 15 subclasses of PLs were quantified by 31-phosphorus nuclear magnetic resonance spectroscopy, and all human milk samples contained 12 subclasses of PLs (sphingomyelin, dihydrosphingomyelin, phosphatidylcholine, lysophosphatidylcholine, alkyl-acyl phosphatidylcholine, choline plasmalogen, phosphatidylserine, phosphatidylinositol, phosphatidyl ethanolamine, lysophosphatidyl ethanolamine, ethanolamine plasmalogen and phosphatidic acid). ${ }^{34}$ The PL concentrations in human milk were similar to those obtained previously, while choline-containing glycerophospholipids were associated with DHA concentrations in human milk. ${ }^{34}$ These results can contribute to a better understanding of the PL profile in Japanese human milk and to the design of a milk fat globule membraneenriched infant formula.

\section{Future plans}

We established a cohort of Japanese lactating women and obtained baseline data for a series of maternal and child characteristics and milk macronutrients. We will continue to measure milk macronutrient composition up to 12 
months postpartum and plan to clarify the relationship between these characteristics and milk macronutrients, including longitudinal associations throughout the postpartum period and seasonal changes based on the data obtained over 12 months. At the end of 5 years of data collection, we aim to investigate the relationship between the macronutrient composition in human milk and childrelated factors such as growth, development and health conditions, including allergies and infectious diseases. Further comprehensive studies of the mother-milkinfant triad may shed light on hidden associations, apart from clarifying the existing factors, between maternal factors and outcomes of their children.

In addition to providing a source of nutrition for infants, human milk contains a myriad of bioactive factors promoting survival and health, including vitamins, immune components and human milk oligosaccharides (HMOs). For example, HMOs in human milk vary individually throughout lactation and play a variety of roles in the formation of gut microbiota and immune developments in infants. ${ }^{45}$ Since this study will collect substantial amount of human milk longitudinally, it has the potential to analyse the wide variety of human milk compositions and reveal a wider range of mother-milk-infant triad relationships.

We plan to evaluate the lifestyle and environmental factors that influence maternal and infant health or breastfeeding practices, including the relationship between maternal child rearing-related stress and breastfeeding practices, maternal eating patterns and postpartum weight retention, and smoking habits of parents and development of their children. We believe that the findings of this study will contribute to the promotion of breastfeeding practices and the elucidation of human milk composition for the benefit of women and their children.

\section{Strengths and limitations}

\section{Strengths}

First, we were able to establish a Japanese Human Milk Study birth cohort of over 1000 women-infant dyads nationwide and obtain corresponding human milk samples. Second, the proportion of women who were exclusively breast feeding (approximately three-quarters) was higher than the corresponding rates reported by the national census $(51 \%$ at 1 month and $55 \%$ at 3 months after delivery), ${ }^{46}$ thus allowing us to explore the mothermilk-infant triads within the profound context of breast feeding. Third, we collected human milk samples from almost all participants (1079/1122, 96\%) at baseline, and the amounts collected were sufficient for comprehensive compositional analyses. These profiles were partly attributed to the study design, since the inclusion criteria, that is, 'healthy lactating women who had delivered infants and had not disrupted their breastfeeding patterns when providing human milk samples for this study' seemed to affect the cohort profile. ${ }^{14}$ In this study, since women who could not breast feed adequately were excluded at enrolment, fewer women would be expected to drop out because of the requirement to collect milk samples. We believe that the higher rate of breastfeeding practice, the more efficient collection rate; consequently, this substantial amount of milk samples will facilitate the analysis of a wide variety of human milk components and investigation of the relationships of mother-milk-infant triads with socioenvironmental factors.

\section{Limitations}

One of our study's limitations is that the generalisability of our results may be limited and requires careful interpretation. First, the percentage of multiparous women in our study population $(65 \%)$ was greater than that reported in the national vital statistics in $2016(53 \%) .{ }^{47}$ Moreover, in comparison with the corresponding proportions reported in the general population, our cohort showed a lower proportion of caesarean deliveries $\left(12 \%\right.$ vs $\left.19 \%{ }^{48}\right)$, preterm births $\left(2.4 \%\right.$ vs $\left.5.6 \%{ }^{47}\right)$ and low-birthweight infants $\left(4.3 \%\right.$ vs $\left.9.4 \%{ }^{47}\right)$. In short, our participants appeared to be healthier than the general population in Japan. These factors are associated with human milk expression during early lactation and may be influenced by the inclusion criteria. ${ }^{49-51}$ In fact, $38 \%$ of our study cohort had a household income of $>6$ million JPY/year, which was slightly higher than that $(27 \%)$ of the largest nationwide birth cohort with 100148 children and parents. ${ }^{52}$ Women achieved relatively higher education than their partners $(77.6 \%$ of women had attended college, university, or higher vs $66.4 \%$ of the partners) and women in the aforementioned nationwide birth cohort $(63.7 \%){ }^{52}$ Such high educational attainment may influence favourable outcomes of interest. In addition, the voluntary participation may result in a selection bias. Other study limitations were the lack of information on maternal nutrition and lifestyle during pregnancy.

\section{COLLABORATION}

Data are available on reasonable request. Proposals for collaboration on human milk and data analysis should be sent to Keisuke Nojiri (keisuke-nojiri@beanstalksnow.co. jp). They will be considered by the Japanese Human Milk Study team.

Correction notice This article has been corrected since it was first published. The corresponding author email has been corrected to hiroshi-ueno@meg-snow.com.

Acknowledgements The authors thank all the study participants who supplied human milk samples and who completed the questionnaires for this study. The authors also acknowledge the contributions of the entire Japanese Human Milk Study team to the set-up and operation of this study. Finally, the authors acknowledge the assistance provided by Tomomi Miyazono and Maki Azakami for collecting human milk samples and participant data for this study.

Contributors Conceptualisation: KNoj and HMU; data curation, formal analysis and writing of original draft: KNoj; funding acquisition: J-iY and YTo; investigation: KNoj, SK, SH, TT, YTs, YTo, J-iY and HMU; methodology: SK; project administration: YTo; software: KNoj; supervision: J-iY, YTo and HMU; validation: SH; visualisation: KNoj and $\mathrm{HMU}$; writing of review and editing: HMU, KNom, YTo and SH. Garantors are KNoj, YTo and HMU. 
Funding This study was supported by Bean Stalk Snow Co., Ltd, and Megmilk Snow Brand Co., Ltd.

Competing interests KeN, SH, TT, YTs and YTo are employees of Bean Stalk Snow. SK, J-iY and HMU were past employees of Bean Stalk Snow and currently employees of Megmilk Snow Brand. Bean Stalk Snow manufactured and sold infant formula and dietary supplements for pregnant and lactating women in Japan. Megmilk Snow Brand manufactured and sold infant formula in Japan, Taiwan, Hong Kong and Malaysia. The other author declares no conflicts of interest.

Patient consent for publication Not applicable.

Ethics approval This study was approved by the Ethics Committee of the Fukuda Internal Medicine Clinic (IRB No. 20140621-03) and registered in the University Hospital Medical Information Network Clinical Trials Registry (UMIN ID 000015494, 2014). All adult participants provided written informed consent in accordance with the Declaration of Helsinki. Participants gave informed consent to participate in the study before taking part. They also gave their consent for assessments on minors.

Provenance and peer review Not commissioned; externally peer reviewed.

Data availability statement Data are available upon reasonable request. Data published in all tables of this article are available from Keisuke Nojiri (keisukenojiri@beanstalksnow.co.jp) through a review of the request.

Supplemental material This content has been supplied by the author(s). It has not been vetted by BMJ Publishing Group Limited (BMJ) and may not have been peer-reviewed. Any opinions or recommendations discussed are solely those of the author(s) and are not endorsed by BMJ. BMJ disclaims all liability and responsibility arising from any reliance placed on the content. Where the content includes any translated material, BMJ does not warrant the accuracy and reliability of the translations (including but not limited to local regulations, clinical guidelines, terminology, drug names and drug dosages), and is not responsible for any error and/or omissions arising from translation and adaptation or otherwise.

Open access This is an open access article distributed in accordance with the Creative Commons Attribution Non Commercial (CC BY-NC 4.0) license, which permits others to distribute, remix, adapt, build upon this work non-commercially, and license their derivative works on different terms, provided the original work is properly cited, appropriate credit is given, any changes made indicated, and the use is non-commercial. See: http://creativecommons.org/licenses/by-nc/4.0/.

\section{ORCID iD}

Hiroshi M Ueno http://orcid.org/0000-0002-8293-9163

\section{REFERENCES}

1 Butte N, Lopez-Alaracon M, Garza C. Nutrient adequacy of exclusive breastfeeding for the term infant during the first six months of life. Geneva, Switzerland: World Health Organization, 2002: 1-37.

2 Victora CG, Bahl R, Barros AJD, et al. Breastfeeding in the 21st century: epidemiology, mechanisms, and lifelong effect. Lancet 2016;387:475-90.

3 Christian P, Smith ER, Lee SE, et al. The need to study human milk as a biological system. Am J Clin Nutr 2021;113:1063-72.

4 Samuel TM, Zhou Q, Giuffrida F, et al. Nutritional and Non-nutritional composition of human milk is modulated by maternal, infant, and methodological factors. Front Nutr 2020;7:576133.

5 Brenna JT, Varamini B, Jensen RG, et al. Docosahexaenoic and arachidonic acid concentrations in human breast milk worldwide. Am J Clin Nutr 2007;85:1457-64.

6 OECD family database. Available: http://www.oecd.org/els/family/ database.htm [Accessed 10 Sep 2021].

7 Murai U, Nomura K, Kido M, et al. Pre-pregnancy body mass index as a predictor of low birth weight infants in Japan. Asia Pac J Clin Nutr 2017;26:434-7.

8 Ogawa K, Morisaki N, Sago H. Association between women's perceived ideal gestational weight gain during pregnancy and pregnancy outcomes. Sci Rep 2018;1:11574.

9 Furuichi E, Doi T, Imamura M. Studies on human milk (Part 1). Preliminary examination on chemical composition of composite milk from mothers in Sapporo. J Japanese Soc Food Nutr 1962;15:135-9.

10 Matsuoka Y, Idota T. The concentration of epidermal growth factor in Japanese mother's milk. J Nutr Sci Vitaminol 1995;41:241-51.

11 Kawamoto T, Nitta H, Murata K, et al. Rationale and study design of the Japan environment and children's study (JECS). BMC Public Health 2014;14:25.

12 Kishi R, Araki A, Minatoya M, et al. The Hokkaido birth cohort study on environment and children's health: cohort profile-updated 2017. Environ Health Prev Med 2017;22:46.
13 Miyake Y, Tanaka K, Masuzaki Y, et al. Organochlorine concentrations in breast milk and prevalence of allergic disorders in Japanese women. Chemosphere 2011;85:374-8.

14 Nojiri K, Kobayashi S, Higurashi S, et al. Maternal health and nutrition status, human milk composition, and growth and development of infants and children: a prospective Japanese human milk study protocol. Int J Environ Res Public Health 2020;17 doi:10.3390/ ijerph17061869

15 Kobayashi S, Murakami K, Sasaki S, et al. Comparison of relative validity of food group intakes estimated by comprehensive and brief-type self-administered diet history questionnaires against $16 \mathrm{~d}$ dietary records in Japanese adults. Public Health Nutr 2011;14:1200-11.

16 Hashimoto Ket al. Validity of the family-rated Kinder infant development scale (KIDS) for children. Pediatr Ther 2013;03:2.

17 Yoshiko S, Sekimizu S. Mothers' Child Care Stress Scale (CSS): development and Validity of a short-form scale. Jpn J Child Abus Negl 2010;12:261-70.

18 Body mass index. Nutrition. BMI-WHO/Europe. Available: https:// www.euro.who.int/en/health-topics/disease-prevention/nutrition/ahealthy-lifestyle/body-mass-index-bmi [Accessed 25 May 2021].

19 Ministry of Health, Labour and Welfare, Japan. Comprehensive survey of living conditions, 2016. Available: https://www.mhlw.go.jp/ toukei/saikin/hw/k-tyosa/k-tyosa16/ [Accessed 10 Sep 2021].

20 Bzikowska-Jura A, Czerwonogrodzka-Senczyna A, Olędzka G, et al. Maternal nutrition and body composition during breastfeeding: association with human milk composition. Nutrients 2018;10 doi:10.3390/nu10101379

21 Be'er M, Mandel D, Yelak A, et al. The effect of physical activity on human milk macronutrient content and its volume. Breastfeed Med 2020;15:357-61.

22 de Fluiter KS, Kerkhof GF, van Beijsterveldt IALP, et al. Longitudinal human milk macronutrients, body composition and infant appetite during early life. Clin Nutr 2021;40:3401-8.

23 Groh-Wargo S, Valentic J, Khaira S, et al. Human milk analysis using mid-infrared spectroscopy. Nutr Clin Pract 2016;31:266-72.

24 Mitoulas LR, Kent JC, Cox DB, et al. Variation in fat, lactose and protein in human milk over $24 \mathrm{~h}$ and throughout the first year of lactation. Br J Nutr 2002;88:29-37.

25 Demmelmair H, Koletzko B. Lipids in human milk. Best Pract Res Clin Endocrinol Metab 2018;32:57-68.

26 Kent JC, Mitoulas LR, Cregan MD, et al. Volume and frequency of breastfeedings and fat content of breast milk throughout the day. Pediatrics 2006;117:e387-95.

27 Leghi GE, Netting MJ, Middleton PF, et al. The impact of maternal obesity on human milk macronutrient composition: a systematic review and meta-analysis. Nutrients 2020;12 doi:10.3390/ nu12040934

28 Lönnerdal B, Erdmann P, Thakkar SK, et al. Longitudinal evolution of true protein, amino acids and bioactive proteins in breast milk: a developmental perspective. J Nutr Biochem 2017;41:1-11.

29 Perrin MT, Festival J, Starks S, et al. Accuracy and reliability of infrared Analyzers for measuring human milk macronutrients in a milk bank setting. Curr Dev Nutr 2019;3:nzz116.

30 Fusch G, Rochow N, Choi A, et al. Rapid measurement of macronutrients in breast milk: how reliable are infrared milk analyzers? Clin Nutr 2015;34:465-76.

31 Bruun S, Jacobsen LN, Ze X, et al. Osteopontin levels in human milk vary across countries and within lactation period: data from a multicenter study. J Pediatr Gastroenterol Nutr 2018;67:250-6.

32 Ueno HM, Higurashi S, Shimomura Y, et al. Association of DHA concentration in human breast milk with maternal diet and use of supplements: a cross-sectional analysis of data from the Japanese human milk study cohort. Curr Dev Nutr 2020;4:nzaa105.

33 Tsugawa N, Nishino M, Kuwabara A, et al. Comparison of vitamin $\mathrm{D}$ and 25-hydroxyvitamin D concentrations in human breast milk between 1989 and 2016-2017. Nutrients 2021;13 doi:10.3390/ nu13020573

34 Ueno HM, MacKenzie A, Scott D, et al. Milk phospholipid profiling among Japanese women with differing docosahexaenoic acid levels. JPGN Rep 2021;2:e058.

35 Kahles F, Findeisen HM, Bruemmer D. Osteopontin: a novel regulato at the cross roads of inflammation, obesity and diabetes. Mol Metab 2014;3:384-93.

36 Schack L, Lange A, Kelsen J, et al. Considerable variation in the concentration of osteopontin in human milk, bovine milk, and infant formulas. J Dairy Sci 2009;92:5378-85.

37 Demmelmair H, Prell C, Timby N, et al. Benefits of lactoferrin, osteopontin and milk fat globule membranes for infants. Nutrients 2017:9 doi:10.3390/nu9080817 
38 Innis SM. Impact of maternal diet on human milk composition and neurological development of infants. Am J Clin Nutr 2014;99:734S-41.

39 Yuhas R, Pramuk K, Lien EL. Human milk fatty acid composition from nine countries varies most in DHA. Lipids 2006;41:851-8.

40 Wang L, Shimizu Y, Kaneko S, et al. Comparison of the fatty acid composition of total lipids and phospholipids in breast milk from Japanese women. Pediatr Int 2000;42:14-20.

41 Koletzko B, Boey CCM, Campoy C, et al. Current information and Asian perspectives on long-chain polyunsaturated fatty acids in pregnancy, lactation, and infancy: systematic review and practice recommendations from an early nutrition academy workshop. Ann Nutr Metab 2014;65:49-80.

42 Yoshikata H, Tsugawa N, Watanabe Y, et al. 25-Hydroxyvitamin D profiles and maternal bone mass during pregnancy and lactation in Japanese women. J Bone Miner Metab 2020;38:99-108.

43 Hernell O, Timby N, Domellöf M, et al. Clinical benefits of milk fat globule membranes for infants and children. J Pediatr 2016;173:S60-5.

44 Cilla A, Diego Quintaes K, Barberá R, et al. Phospholipids in human milk and infant formulas: benefits and needs for correct infant nutrition. Crit Rev Food Sci Nutr 2016;56:1880-92.

45 Bode L. Human milk oligosaccharides: every baby needs a sugar mama. Glycobiology 2012;22:1147-62.
46 Ministry of Health, Labour and Welfare, Japan. National nutrition survey on preschool children 2015. Available: https://www.mhlw.go. jp/stf/seisakunitsuite/bunya/0000134208.html [Accessed 25 May 2021]

47 Ministry of Health, Labour and Welfare Japan. Vital statistics 2016. Available: https://www.mhlw.go.jp/toukei/list/81-1.html [Accessed 25 May 2021].

48 Maeda E, Ishihara O, Tomio J, et al. Cesarean section rates and local resources for perinatal care in Japan: a nationwide ecological study using the National database of health insurance claims. J Obstet Gynaecol Res 2018;44:208-16.

49 Huang $Y$, Ouyang $Y-Q$, Redding SR. Previous breastfeeding experience and its influence on breastfeeding outcomes in subsequent births: a systematic review. Women Birth 2019;32:303-9.

50 Prior E, Santhakumaran S, Gale C, et al. Breastfeeding after cesarean delivery: a systematic review and meta-analysis of world literature. Am J Clin Nutr 2012;95:1113-35.

51 Callen J, Pinelli J. A review of the literature examining the benefits and challenges, incidence and duration, and barriers to breastfeeding in preterm infants. Adv Neonatal Care 2005;5:72-88.

52 Michikawa T, Nitta H, Nakayama SF, et al. Baseline profile of participants in the Japan environment and children's study (JECS). J Epidemiol 2018;28:99-104. 